\title{
EFFECTS OF FLIPPED CLASSROOM TECHNOLOGY ON STUDENTS' INTEREST AND ACHIEVEMENT IN ENGLISH LANGUAGE READING COMPREHENSION
}

\author{
OMILE, JACINTA CHINWE (Ph.D) $)^{1}$, ULOH-BETHELS, ANNAH CHINYEAKA (Ph.D) ${ }^{2^{*}}$, UGWUANYI, \\ EUCHARIA IJEOMA (Ph.D) $)^{3}$, OBIEZU, MAUREEN NNENNA ${ }^{4}$, OSIGWE, NNEKA $A^{5}$ \\ \& EZEIFE, ONYINYE NOELEEN ${ }^{6}$ \\ ${ }^{1,3,4,5,6}$ Department of English, Federal College of Education (Technical), Umunze \\ ${ }^{2}$ Department of Arts Education, University of Nigeria Nsukka
}

\begin{abstract}
The paper examined the effect of Flipped Classroom Technology (FCT) on students' reading comprehension. FCT is a learner-centered instructional technology where the teachers' role and out-of-class contents are reversed in learning. The study adopted the quasi-experimental research design using a sample of 80 Junior Secondary two (JS 2) students. The instrument for data collected was English Language Reading Comprehension Test developed by the researchers and properly validated. The instrument demonstrated good inter-rater reliability index of 0.89 using Kendall coefficient of concordance. Data were analyzed using mean and Analysis of Covariance. The results indicated that FCT had significant $(p<.05)$ effects on students' interest and achievement in English language reading comprehension in teaching reading comprehension. This implies that students' readiness, interest, achievement and mastery of reading comprehension would be greatly enhanced when teachers adopt the use of FCT. Based on the findings of the study, it was recommended that secondary school teachers should adopt FCT in teaching reading comprehension.

KEYWORDS: English Language Comprehension, Flipped Classroom Technology \& Online Reading Technology
\end{abstract}

Received: May 19, 2021; Accepted: Jun 11, 2021; Published: Jun 21, 2021; Paper Id.: IJMPERDAUG202113

\section{INTRODUCTION}

In this era of information and communication technology, use of online reading technology or flipped classroom technology in teaching students reading comprehension is very effective. In support of the above assertion, significant impacts of information communication technology have been found on students' performance in Mathematics (Onah et al., 2020); in Science (Ugwuanyi et al., 2020 a,b,c; Ugwuanyi \& Okeke, 2020; Ugwuanyi et al., 2019a, 2019b) and in Social Science courses (Ejimonye et al., 2020a, 2020b). Bloom (2001) in his revised taxonomy of education stated that through the use of flipped classroom, students can undertake the lower levels of cognitive work (gaining knowledge) on their own. This makes reading more flexible than it would be for the traditional classroom. It also enables students' access to course contents ahead of class. By so doing, the students come to class fully prepared.

In a flipped classroom, students are presented with recorded lectures to view at home after which they will present what they have learnt during the class activities (Bergmann \& Sams, 2014). According to Adonu et al. (2021), flipped classroom is a method of teaching and learning which enables the students to watch a video lesson or recorded lectures outside of class. Flipped classroom instructional approach has to do with the assignment of video lectures to the students for homework instead of the traditional classroom instructional lectures (Ugwuanyi et 
al., 2019b). Teachers who adopt this technology in teaching reading comprehension look slightly different from the traditional model. This technology in teaching reading comprehension gives the students the opportunity to re-watch all or parts of the video. The application of flipped classroom in teaching and learning makes students perceive reading comprehension as more engaging. Besides, teaching reading comprehension through the application of flipped classroom enhances students' written responses to texts. This can be done by allowing the students watch a visual media presentation on their own before coming to the classroom to make a presentation of what they have learnt.

Previous empirical studies have revealed the effect of flipped classroom on students' learning. Learning using flipped classroom approach was found to be significantly more interesting by students than the conventional approach (Price \& Walker, 2021). The use of flipped classroom in teaching and learning yields better learning performance among the students (Ekici, 2021). Flipped classroom application increases the effectiveness of instructional by increasing student engagement in the learning process (Rotellar \& Cain, 2016). The implementation of flipped classroom has a significant effect on academic achievement in Science classes (Doğan et al., 2021). The application of flipped classroom strategy improves students' performance and satisfaction in the learning process (Joseph et al., 2021). The use of flipped classroom approach enhances students' academic achievement, more than other classroom models (Polat \& Karabatak, 2021). Students' Englishspeaking performance significantly improved after their exposure to flipped classroom technology (Chang \& Lan, 2021).

\section{Statement of Problem}

Today students are so oriented to technology that they concentrate more on their smartphones, computers, iPad and other electronic devices than reading from textbooks. Parents do not pay attention to their children or spend quality time monitoring the progress of their children and this has become a sort of worry to many individuals. Some teachers have chosen to adopt the flipped classroom model wherein the students view recorded lessons at home and then use class time for group discussion and teacher's assignments. Trucano (2005) opined that the integration of Information Communication Technology empowers teachers and learners, transforming teaching and learning processes from being highly teacher-dominated to being studentcentered. Thus, adopting flipped classroom technology will aim at enhancing the students' reading proficiency to redirect the student's mind to the use of media facilities.

This research therefore sought to determine the effects of flipped classroom technology on students' interest and achievement in reading comprehension. Thus, the researchers formulated the following hypotheses.

Ho1: There is no significant difference in the mean interest scores of students taught reading comprehension using flipped classroom technology and those not so exposed.

Ho2: There is no significant difference in the mean achievement scores of students taught reading comprehension using flipped classroom technology and those no so exposed.

\section{METHOD}

\section{Research Design}

The research adopted pretest, posttest non-equivalent control group quasi-experimental research design. According to Ali (2006), quasi - experimental design enables researchers the opportunity to avoid disruption of normal class lessons by using intact classes. Recently, Odo et al. (2021), Njoku et al. (2020), Offordile et al. (2021), Adene et al. (2021), Adonu et al. (2021), Ejimonye et al. (2020a, b) have adopted this design in their similar studies. 


\section{Sample and Sampling Technique}

The sample of this study comprised eighty (80) JS 2 students sampled from a population of 835 Junior Secondary School Two (JS 2) students in all the registered public schools in the urban part of Awka South Local Government Area of Anambra State. This sample came from two schools drawn purposively from the 22 public secondary schools study area. The choice of these two sampled schools was because of the location of the schools which is at the center of the area with internet facilities.

\section{Validation and Reliability of the Instrument}

The instrument used for data collection was English Language Reading Comprehension Test developed by the researchers. The items of the instrument comprised reading comprehension passages and questions only. The instrument was properly faced and content validated by three experts in test development and construction. The instrument was trial tested on equivalent subjects prior to the actual data collection. The instrument demonstrated a good inter-rater reliability index of 0.89 using Kendall coefficient of concordance.

\section{Experimental Procedure}

The experiment spread out in a six weeks span. In the first week, the researchers administered a written pretest on reading comprehension to get the baseline data for the study. For the subsequent weeks, the researchers taught the students in one of the schools (control group) using the traditional method of teaching reading comprehension. On the other hand, they also sent videos of the recorded comprehension passages to the students (experimental group) in the second school via YouTube, WhatsApp, Facebook and Instagram. At the end of the six weeks, the same questions used for the pretest were set for the students in the two schools as a posttest. The data gotten from the pretest and posttest was then be forwarded for statistical analysis.

\section{Method of Data Analysis}

Data were analysed using mean and Analysis of Covariance (ANCOVA) in order to answer the research questions and test the hypotheses at 0.05 level of significance. The pretest scores were used as covariate to the posttest scores. The ANCOVA was employed to part out the initial differences between the two experimental groups.

\section{RESULTS}

Research Question One: What are the mean interest scores of students taught reading comprehension using flipped classroom technology and those taught using the traditional classroom method.

Table 1: Mean Analysis of Interest Scores of Students of Experimental and Control Groups

\begin{tabular}{|l|c|c|c|c|c|c|}
\hline \multicolumn{1}{|c|}{ Group } & \multicolumn{3}{c|}{ Pretest } & \multicolumn{2}{c|}{ Posttest } & \\
\hline & $\mathrm{n}$ & Mean & SD & Mean & SD & Mean Gain \\
\hline Flipped classroom method & 42 & 36.67 & 9.48 & 50.51 & 12.63 & 13.84 \\
\hline Traditional teaching method & 38 & 34.09 & 10.75 & 45.97 & 6.18 & 11.88 \\
\hline
\end{tabular}

Table 1 shows that the experimental group students had a posttest mean interest score of $(M=50.51, S D=12.63)$, while the control group students had a mean interest score of $(M=45.97, S D=6.18)$ at the post-test.

Ho1: There is no significant difference in the mean interest scores of students taught reading comprehension using flipped classroom technology and those not so exposed. 
Omile, Jacinta Chinwe, Uloh-Bethels, Annah Chinyeaka*, Ugwuanyi, Eucharia Ijeoma, Obiezu, Maureen Nnenna, Osigwe, Nneka A \& Ezeife, Onyinye Noeleen

Table 2: Analysis of Variance of the Effect of Flipped Classroom Technology on Students' Interest in Reading Comprehension

\begin{tabular}{|c|c|c|c|c|c|}
\hline Source & Type III Sum of Squares & df & Mean Square & $\mathbf{F}$ & Sig. \\
\hline Corrected Model & $4801.276^{\mathrm{a}}$ & 2 & 2400.638 & 18.178 & .000 \\
\hline Intercept & 2963.924 & 1 & 2963.924 & 22.443 & .000 \\
\hline Pretest & 645.847 & 1 & 645.847 & 4.890 & .030 \\
\hline Treatment & 3977.174 & 1 & 3977.174 & 30.115 & .000 \\
\hline Error & 10169.111 & 77 & 132.066 & & \\
\hline Total & 144817.000 & 80 & & & \\
\hline Corrected Total & 14970.387 & 79 & & & \\
\hline
\end{tabular}

Table 2 revealed that there is a significant effect of flipped classroom technology on students' interest in reading comprehension, $F(1,77)=30.115, p=.000$. This led to the rejection of the null hypothesis $(p<.05)$.

Research Question Two: What are the mean achievement scores of students taught reading comprehension using flipped classroom technology and those taught without flipped classroom method?

Table 3: Mean Analysis of Achievement Scores of Students of Experimental and Control Groups

\begin{tabular}{|l|c|c|c|c|c|c|}
\hline \multicolumn{1}{|c|}{ Group } & \multicolumn{3}{c|}{ Pretest } & \multicolumn{2}{c|}{ Posttest } & \\
\hline & n & Mean & SD & Mean & SD & Mean Gain \\
\hline Flipped classroom method & 42 & 8.15 & 3.63 & 25.98 & 2.59 & 17.83 \\
\hline Traditional teaching method & 38 & 4.25 & 1.42 & 10.50 & 1.58 & 6.25 \\
\hline
\end{tabular}

Table 3 shows that the experimental group students had a posttest mean achievement score of $(M=25.98, S D=$ $2.59)$, while the control group students a posttest mean achievement score of $(M=10.50, S D=1.58)$.

Ho2: There is no significant difference in the mean achievement scores of students taught reading comprehension using flipped classroom technology and those no so exposed.

Table 4: Analysis of Variance of the Effect of Flipped Classroom Technology on Students' Achievement in Reading Comprehension

\begin{tabular}{|l|c|c|c|c|c|}
\hline \multicolumn{1}{|c|}{ Source } & $\begin{array}{c}\text { Type III Sum of } \\
\text { Squares }\end{array}$ & df & Mean Square & F & Sig. \\
\hline Corrected Model & $1530.830^{\mathrm{a}}$ & 2 & 765.415 & 80.086 & .000 \\
\hline Intercept & 476.463 & 1 & 476.463 & 49.853 & .000 \\
\hline Pretest & .125 & 1 & .125 & .013 & .909 \\
\hline Treatment & 1530.322 & 1 & 1530.322 & 160.119 & .000 \\
\hline Error & 735.920 & 77 & 9.557 & & \\
\hline Total & 20568.000 & 80 & & & \\
\hline Corrected Total & 2266.750 & 79 & & & \\
\hline a. R Squared =.675 (Adjusted R Squared =.667)
\end{tabular}

Table4 revealed that there is a significant effect of flipped classroom technology on students' achievement in reading comprehension, $F(1,77)=160.119, p=.000$. This led to the rejection of the null hypothesis $(p<.05)$.

\section{DISCUSSIONS}

This study sought to determine the effects of flipped classroom technology on students' interest and achievement in reading 
comprehension. The findings indicated that flipped classroom technology had significant effects on students' interest and achievement in reading comprehension. The efficacy of flipped classroom technology over the traditional teaching method is not surprising because of the interactive nature of flipped classroom technology (Bishop \& Verleger, 2013). Flipping our classrooms means speaking the digital language our students understand and infiltrating the video-digital culture of learning in schools.

Buttressing these findings, Baki and Khaled (2016) found that flipped classroom had significant effect on students' achievement in mathematics. Students' English-speaking performance significantly improved after their exposure to flipped classroom technology (Chang \& Lan, 2021). The application of flipped classroom strategy improves students' performance and satisfaction in the learning process (Joseph et al., 2021). The use of flipped classroom approach enhances students' academic achievement, more than other classroom models (Polat \& Karabatak, 2021). Muhammad and Falalu (2016) revealed that flipped classroom model significantly enhanced students' achievement in integrated science. The use of flipped classroom in teaching and learning yields better learning performance among the students (Ekici, 2021). Similarly, flipped classroom instructional approach significantly enhanced students' achievement in physics (Ugwuanyi et al., 2019b). Adonu et al. (2021) similarly found that flipped classroom instructional approach significantly enhanced students' achievement in Biology. These findings have corroborated the instructional efficacy of flipped classroom technology on students' academic achievement.

Flipped classroom application increases effectiveness of instructional by increasing student engagement in the learning process (Rotellar \& Cain, 2016). Learning using flipped classroom approach was found to be significantly more interesting by students than the conventional approach (Price \& Walker, 2021). The implementation of flipped classroom has a significant effect on academic achievement in Science classes (Doğan et al., 2021).

\section{CONCLUSIONS AND RECOMMENDATIONS}

On the strength of the findings of this research, the following conclusions are hereby drawn. The flipped classroom technology method has facilitative effects on secondary school students' interest and achievement in reading comprehension. Based on the findings of the study, the following recommendations were made:

- It was recommended that secondary school English language teachers should adopt FCT in teaching reading comprehension since the results of the study has shown that the FCT significantly has a positive effect on secondary school students.

- It was also recommended that education authorities should train and empower teachers to use FCT in teaching reading comprehension through conducting seminars, workshops, conferences aimed at creating awareness of the technology and its implementation.

\section{ACKNOWLEDGEMENTS}

The researchers are thankful to all the subjects used for the study as well as Dr. Annah Chinyeaka Uloh-Bethels of the Department of Arts Education, University of Nigeria, who served as the corresponding author for this research.

\section{REFERENCES}

1. Adene, F.M., Umeano, E.C., Adimora, D.E., Ugwuanyi, C.S., Okeke, C.I.O., Offordile, E.E., Amaeze, F.E., Uzodinma, U.E., Abdullahi, Y., Ejiofor, J.N. \& Ishiwu, E.N. (2021). Effectiveness of Peer Collaborative Learning Strategy on Self-Esteem of 
Pupils with Behaviour Problems in Nsukka Education Authority. Journal of Critical Reviews, 8(1), 1055-1069. http://www.jcreview.com/fulltext/197-1615692041.pdf?1615708380

2. Adonu, C.J., Nwagbo, C.R., Ugwuanyi, C.S., \& Okeke, C.I.O. (2021). Improving Students' Achievement and Retention in Biology using Flipped Classroom and Powerpoint Instructional Approaches: Implication for Physics Teaching. International Journal of Psychosocial Rehabilitation, 25(2), 234-247. https://www.psychosocial.com/article/PR320026/37829/

3. Tippabhotla Vyomakesisri, “Challenges in Learning English as Secondary Language”,International Journal of English And Literature (IJEL), Vol. 7, Issue 6,pp, 21-24

4. Ali, A. (2006). Conducting Research in Education and the Social Science. Enugu: Tashiwa Networks Ltd

5. Bairagi Patra \& Ashok Kumar Mohanty, "Importance of English for Engineering Students: An Evaluation of the Prevalent Teaching-Learning System in the Indian Context 'International Journal of English and Literature (IJEL),Vol. 6, Issue 4,pp, 21 34

6. Baki, M. D. \& Khaled, M. A. (2016). The effect of using flipped classroom instruction on students' achievement in new scholastic assessment test mathematics skills. (Unpublished M.Ed project). United Emirates University.

7. Oktay Yağiz \& Siros Izadpanah, "The Listening Strategies of Iranian EFL Scholars: A StrategyBased Approach to Listening to Oral English Texts ",International Journal of Linguistics and Literature (IJLL), Vol. 4, Issue 1,pp, 7-18

8. Bergamann J. \& Sams A. (2014). Flipped Learning: Gateway to Student Engagement.First edition; Washington DC: International Society for Technology in Education.

9. Bishop, J. L. \& Verleger, M. A. (2013). The Flipped Classroom: A Survey of the Research. A survey of the research. 120th American Society for Engineering education Annual Conference and Exposition, 30. 1 - 18

10. S. Meenakshi, M. Prema \& P. Vijayapriya, "Is the Acquisition of English as a Second Language Still a Perennial Problem to the Rural Students of Tamil Nadu ",International Journal of Humanities and Social Sciences (IJHSS), Vol. 6, Issue 5,pp; 25-32

11. Bloom, B. S. (2001). A Taxonomy for Learning, Teaching and Assessing: a revision of

12. Bloom's taxonomy of educational objectives. Pennysylvania States University; Longman Publishers

13. Chang, M. M., \& Lan, S. W. (2021). Flipping an EFL classroom with the LINE application: students' performance and perceptions. Journal of Computers in Education, 0123456789. https://doi.org/10.1007/s40692-020-00179-0

14. Doğan, Y., Batdl, V., \& Yaşar, M. D. (2021). Effectiveness of flipped classroom practices in teaching of science: a mixed research synthesis. Research in Science \& Technological Education, 00(00), 1-29. https://doi.org/10.1080/02635143.2021.1909553

15. Ejimonye, J.C., Onuoha, J.C., Ugwuanyi, C.S., Eneogu, N.D., Ugwuanyi, B.E \& Ogbuehu, S.N (2020a). Effectiveness of TwoDimensional Animation Technique in Enhancing Students' Motivation in Quantitative Economics Concepts. International Journal of Future Generation Communication and Networking (IJFGCN), 13(1):27-38.

16. Ejimonye, J.C., Ugwuanyi, C.S., Okeke, C.I.O., \& Nwoye, M.N. (2020b). Two-Dimensional Animation and Students' Achievement in Mathematical Economics: Implications for Science Teaching. International Journal of Engineering Research and Technology, 13(6), 1220-1230

17. Ekici, M. (2021). A systematic review of the use of gamification in flipped learning. Education and Information Technologies. https://doi.org/10.1007/s10639-020-10394-y

18. Joseph, M. A., Roach, E. J., Natarajan, J., Karkada, S., \& Cayaban, A. R. R. (2021). Flipped classroom improves Omani nursing 
students performance and satisfaction in anatomy and physiology. BMC Nursing, 20(1), 1-10. https://doi.org/10.1186/s12912020-00515-w

19. Muhammad, B. A. \& Falalu, M. K. (2016). Impact of flipped classroom model on academic performance among 200 level integrated science students in properties of matter concepts, Zaria Local Government. $57^{\text {th }}$ Annual conference proceedings of STAN, STAN publications, Ibadan: $268-273$.

20. Njoku, M.I.A., Nwagbo, C.R., \& Ugwuanyi, C.S. (2020). Effect of Peer Tutoring and Peer-Led Team Learning on Students' Achievement in Biology. International Journal of Database Theory and Application (IJDTA), 13(1),1-10. https://doi.org/10.33832/ijdta.2020.13.1.01.

21. Odo, I.O., Agwagah, U.N.V., Ugwuanyi, C.C., Shiaki, O.B., Nwoye, M.N., Emeji, E.I., Okeke, A.M., Osakwe, I.J., Okeke, C.I.O., \& Ugwuanyi, C.S. (2021). Effectiveness of First Principles of Instruction in Promoting high Achievement of students in Mathematics: Implications for physics teaching. Journal of Critical Reviews, 8(2), 119-128. ISSN- 2394-5125. http://www.jcreview.com/fulltext/197-1616736017.pdf?1616753765

22. Offordile, E.E., Umeano, E.C., Adene, F.M., Obi, M.C., Ugwuanyi, C.S., Okeke, C.I.O., Adimora, D.E. (2021). Improving the academic achievement of low achieving secondary school students in physics using peer tutoring learning strategy: Implications for Engineering Career. International Journal of Mechanical and Production Engineering Research and Development (IJMPERD), 11(3), 201-212. ISSN (P): 2249-6890; ISSN (E): 2249-8001. http://www.tjprc.org/publishpapers/2-671618048208-15IJMPERDJUN202115.pdf

23. Onah, E.N., Ugwuanyi, C.S., Okeke, C.I.O., Nworgu, B.G., Agwagah, U.V.N., Ugwuanyi, C.C., Obe, P.I., Nwoye, M. N., \& Okeke, A.O. (2020). Evaluation of the Impact of Computer-Assisted Instruction on Mathematics and Physics Students' Achievement: Implication for Industrial Technical Education. International Journal of Engineering Research and Technology, 13(7): 1786-1794. http://irphouse.com/ijert20/ijertv13n7_35.pdf.

24. Polat, H., \& Karabatak, S. (2021). Effect of flipped classroom model on academic achievement, academic satisfaction and general belongingness. Learning Environments Research, 0123456789. https://doi.org/10.1007/s10984-021-09355-0

25. Price, C., \& Walker, M. (2021). Improving the accessibility of foundation statistics for undergraduate business and management students using a flipped classroom. Studies in Higher Education, 46(2), $245-257$. https://doi.org/10.1080/03075079.2019.1628204

26. Rotellar, C., \& Cain, J. (2016). Research, perspectives, and recommendations on implementing the flipped classroom. American Journal of Pharmaceutical Education, 80(2). https://doi.org/10.5688/ajpe80234

27. Trucano, M. (2005). Knowledge maps: ICT in Education. Washington DC: Information for Development/World Bank. Available from: www.infodev.org/en/Document.8.pdf (assessed 19 March, 2019)

28. Ugwuanyi, C.S., Nduji, C.C., Gana, C.S., Nwajiuba, C.A., Ene, C.U., Okeke, A.O., Eseadi, C., Okeke, C.F. (2019b). Effectiveness of flipped classroom instructional technology model in enhancing students' achievement in physics. International Journal of uand e-Service, Science and Technology, 12(4): 37-46.

29. Ugwuanyi, C. S., Okeke, C. I. O., Nnamani, P. A., Obochi, E. C. \& Obasi, C. C. (2020a). Relative effect of animated and nonanimated powerpoint presentations on physics students' achievement. Cypriot Journal of Educational Science. 15(2), $282-291$. https://doi.org/10.18844/cjes.v15i2.4647

30. Ugwuanyi, C.S., Nduji, C.C., Elejere, U.C., \& Omeke, N.E. (2020b). Effect of Flipped Classroom and Think Pair Share Strategy on Achievement and Retention Among Senior Secondary School Physics Students. International Journal of Sciences: Basic and
Applied
Research
(IJSBAR),
52(2),
136-148. 
https://www.gssrr.org/index.php/JournalOfBasicAndApplied/article/view/11250/5681

31. Ugwuanyi, C.S., \& Okeke, C.I.O. (2020). Enhancing University Students 'Achievement in Physics using Computer-Assisted Instruction. International Journal of Higher Education 9(5), 115-124. https://doi.org/10.5430/ijhe.v9n5p115

32. Ugwuanyi, C.S., Okenyi, E.C., Ezema, V., \& Amoke, C. (2020c). Effect of digital game-based learning on achievement of primary school pupils in sciences in Enugu State, Nigeria. Journal of Educational Research on Children, Parents \& Teachers, 1(1), 35 44.

33. Ugwuanyi, C.S., Ugwuanyi, C.C., Ezenwa-Nebife, D.C., Gana, C., Ene, C., Oguguo, B.C., Ikeh, F.E., Okeke, A.O., Nwoye, M.N., Obi, C.N., Anyaegbu, C. \& Agah, J.J. (2019b). Assessment of the efficacy of information and communication technology tool on achievement of students in physics and mathematics: A case of repeated measures. Journal of Engineering and Applied Sciences, 14(13), 4541-4546. 